\title{
Hematological Findings and Clinical Severity in Pediatric Patients with COVID-19
}

\author{
Pediatrik Hastalarda COVID-19'da Hematolojik Bulgular ve Klinik Ciddiyet
}

Pathum Sookaromdee ${ }^{1}$, (D) Viroj Wiwanitkit²

1 Private Academic Consultant, Bangkok, Thailand

2 Patil University, Pune, India

\section{To the Editor,}

We would like to share some ideas on "Can Hematological Findings of COVID-19 in Pediatric Patients Guide Physicians Regarding Clinical Severity?" [1]. Arıkan et al. [1] concluded that the "neutrophil-to-lymphocyte ratio (NLR) was higher in severe/critical cases... Red cell distribution width (RDW) statistically significantly increased in severe cases". We agree that basic hematological parameters might be good indicators for monitoring the severity of many medical problems. Regarding coronavirus disease-19 (COVID-19), NLR and RDW might or might not be useful as predictive parameters for severity in children with COVID-19. RDW might not be useful in many settings. In our setting in Southeast Asia, there is a very high incidence of thalassemia. There are also many pediatric cases of COVID-19. Since these children usually have high RDW as a background hematological finding [2], RDW is not useful for the prediction of COVID-19 severity in these cases. Therefore, RDW is not a useful predictive parameter in any setting with a high incidence of thalassemia. The NLR ratio might be a better predictive parameter. However, it is necessary to set a population-specific reference value for clinical application [3].

Keywords: Hematology, Severity, COVID-19, Pediatric
Anahtar Sözcükler: Hematoloji, Ciddiyet, COVID-19, Pediatrik

Informed Consent: Not applicable.

\section{Authorship Contributions}

Concept: P.S., V.W.; Design: P.S., V.W.; Data Collection or Processing: P.S., V.W.; Analysis or Interpretation: P.S., V.W.; Literature Search: P.S., V.W.; Writing: P.S., V.W.

Conflict of Interest: No conflict of interest was declared by the authors.

Financial Disclosure: The authors declared that this study received no financial support.

\section{References}

1. Arıkan KO, Şahinkaya $S$, Böncüoğlu $E$, Kıymet $E$, Cem $E$, Kara AA, Bayram N, Devrim I. Can hematological findings of COVID-19 in pediatric patients guide physicians regarding clinical severity? Turk J Hematol 2021;38:243245.

2. Flynn MM, Reppun TS, Bhagavan NV. Limitations of red blood cell distribution width (RDW) in evaluation of microcytosis. Am J Clin Pathol 1986;85:445-449.

3. Wang J, Zhang F, Jiang F, Hu L, Chen J, Wang Y. Distribution and reference interval establishment of neutral-to-lymphocyte ratio (NLR), Iymphocyteto-monocyte ratio (LMR), and platelet-to-lymphocyte ratio (PLR) in Chinese healthy adults. J Clin Lab Anal 2021;35:e23935. 


\section{REPLY FROM THE AUTHORS}

We thank the author for their interest in our manuscript, and we acknowledge their concerns regarding use of red cell distribution width (RDW) in clinical diagnosis of severity of COVID-19 infected children in places with very high incidence of thalassemia like Indochina. While we agree that pediatric children usually have a high RDW as a background hematological disease, in our study none of the patients had thalassemia as underlying disease. And published studies support usage hematological parameters including RDW in COVID-19 infected cases.

In a published study, a progressive increase of RDW was observed with advancing COVID-19 severity. Also in multivariate analysis, elevated RDW was associated with 9-fold increased odds of severe COVID-19 [1].

In an other published study, RDW was found to be a prognostic predictor for patients with severe COVID-19, and authors concluded that the increase in reticulocyte may contribute to elevated RDW [2].In a study conducted in 1641 patients, authors concluded that elevated RDW at the time of hospital admission and an increase in RDW during hospitalization were associated with increased mortality risk for patients with COVID-19 [3].

In our findings, the NLR ratio was higher in severe/critical cases compared to cases of asymptomatic, mild, and moderate severity. In a study conducted in 245 COVID-19 patients multivariate analysis demonstrated that there was $8 \%$ higher risk of in-hospital mortality for each unit increase in NLR (odds ratio $[\mathrm{OR}]=1.08 ; 95 \%$ confidence interval $[95 \% \mathrm{Cl}], 1.01$ to 1.14; $P=0.0147)$ [4].

Finally we conclude that hematological parameters of COVID-19 infected pediatric cases may alert physicians about clinical severity. But hematological markers especially RDW should be used correctly as patient-based approach in COVID-19 infected pediatric patients .

\section{References}

1. Henry BM, Benoit JL, Benoit S, Pulvino C, Berger BA, Olivera MHS, Crutchfield CA, Lippi G. Red Blood Cell Distribution Width (RDW) Predicts COVID-19 Severity: A Prospective, Observational Study from the Cincinnati SARSCoV-2 Emergency Department Cohort. Diagnostics (Basel) 2020;10:618.

2. Wang $C$, Zhang $H$, Cao $X$, Deng $R$, Ye $Y$, Fu Z, Gou L, Shao F, Li J, Fu W, Zhang $X$, Ding $X$, Xiao J, Wu C, Li T, Oi H, Li C, Lu Z. Red cell distribution width (RDW): a prognostic indicator of severe COVID-19. Ann Transl Med 2020;8:1230.

3. Foy BH, Carlson JCT, Reinertsen E, Padros I Valls R, Pallares Lopez $R$, Palanques-Tost E, Mow C, Westover MB, Aguirre AD, Higgins JM. Association of Red Blood Cell Distribution Width With Mortality Risk in Hospitalized Adults With SARS-CoV-2 Infection. JAMA Netw Open 2020;3:e2022058.

4. Liu Y, Du X, Chen J, Jin Y, Peng L, Wang HHX, Luo M, Chen L, Zhao Y. Neutrophil-to-lymphocyte ratio as an independent risk factor for mortality in hospitalized patients with COVID-19. J Infect 2020;81:e6-e12.

Kamile Ötiken Arıkan, Şahika Şahinkaya, Elif Böncüoğlu, Elif Kıymet, Ela Cem, Aybüke Akaslan Kara, Nuri Bayram, İlker Devrim 